\title{
ANTIVIRAL ACTIVITY OF AGARICUS BLAZEI MURRILL SS. HEINEM EXTRACT AGAINST HUMAN AND BOVINE HERPESVIRUSES IN CELL CULTURE
}

\author{
Rafaela Bruggemann ${ }^{1}$; Janaina Matsuo Orlandi ${ }^{1}$; Fabricio Jose Benati ${ }^{1}$; Ligia Carla Faccin ${ }^{1}$; \\ Mario Sergio Mantovani ${ }^{2}$; Carlos Nozawa ${ }^{1}$; Rosa Elisa Carvalho Linhares ${ }^{1 *}$
}

${ }^{1}$ Departamento de Microbiologia, Universidade Estadual de Londrina, Londrina, PR, Brasil; ${ }^{2}$ Departamento de Biologia Geral, Universidade Estadual de Londrina, Londrina, PR, Brasil

Submitted: October 17, 2005; Returned to authors for corrections: March 09, 2006; Approved: July 18, 2006

\begin{abstract}
The aqueous extract of Agaricus blazei Murill ss. Heinem, a basidiomycete native from Brazil, frequently used by popular medicine, mainly in the form of tea, was assessed to its antiviral action against herpes simplex type 1 (HSV-1) and bovine herpes type 1 (BoHV-1) in HEp-2 cell culture. Viral replication inhibition was evaluated by plaque assay and immunofluorescence test. The extract demonstrated virucide action for both viruses, being more effective against HSV-1, inhibiting its infectivity in 78.4 and $73.9 \%$ at the concentrations of 50 and $100 \mu \mathrm{g} / \mathrm{mL}$, respectively moreover, reduction in $47 \%$ the number of fluorescent cells was observed for both concentrations. The extract also showed discrete therapeutic activity. These results suggest that $A$. blazei extract acts mainly in the viral particle, however, the effect during virus replication can not be ruled out.
\end{abstract}

Key words: Agaricus blazei, BoHV-1, HSV-1, antiviral activity

\section{INTRODUCTION}

Herpes simplex virus type 1 (HVS-1) and bovine herpesvirus type 1 (BoHV-1) are members of the subfamily Alphaherpesvirinae and possess a double stranded DNA genome, which is involved by an icosahedric capsid and a lipidic envelope with glicoproteins spikes on it. HSV-1 is associated to human oro-facial, ocular infections and encephalitis. BoHV-1 is responsible for infections in bovines, such as those involved with the upper respiratory (rhinotracheitis) and genital tracts (vulvovaginitis) $(9,13,16)$. To date there are approximately 40 drugs which have been officially approved for the chemotherapy of viral infections. Among anti-herpesvirus, acyclovir, pencyclovir, valacyclovir, famcyclovir, idoxuridine, brivudin and trifluridine are used $(2,4,7)$.

The appearance of resistant strains and the toxicity presented by some drugs have stimulated the research for new substances, synthetic or natural, with antiviral activity (6). Fungi secondary metabolites exhibit a large number of biologic activities, making basidiomycetes an alternative target for antiviral research (18). Many fungi have been studied for their nutritional and medicinal properties (3).

Agaricus blazei is a basidiomycete, native from Brazil, and has been frequently used in popular medicine, mainly in the form of tea (14). The fructification body of A. blazei contains $85-87 \%$ of water. When dehydrated, this fungus is rich in proteins (40-45\%), carbohydrates (38-45\%), fibers (6-8\%), lipids (3-4\%) and vitamins, such as B1, B2 and niacin. It also contains ergosterol, which is converted into D2 vitamin. Potassium is the main mineral content of Agaricus blazei (14). Popularly, this fungus is used against physical and mental stress, osteoporosis and gastric ulcer, as stimulatory of immunity and for cholesterol reduction. It is also used as antioxidant, antimutagenic, and anticarcinogenic $(5,8,10,12,19)$. Sorimachi et al. (19) also demonstrated that $A$ blazei inhibited the cytopathic effect of Western Equine Encephalitis Virus.

Apart from Agaricus blazei, compounds from the basidiomycetes Ganoderma pfeifferi and Rozites caperata demonstrated antiviral activity for many viruses, such as herpes simplex $(11,15)$. In this study, we evaluated the action of aqueous

*Corresponding Author. Mailing address: Departamento de Microbiologia, CCB, Universidade Estadual de Londrina, Caixa Postal 6001. 86051-990. Londrina, PR, Brasil. Tel.: (+5543) 3371-4617, Fax: (+5543) 3371-4192. E-mail: relin@uel.br 
extract of A. blazei in the replication of HSV-1 and BoHV-1, in HEp-2 cell culture.

\section{MATERIALS AND METHODS}

\section{Preparation of fungus aqueous extract}

The aqueous extract of A. blazei Murill lineage 99/26 basidiocarp (produced and supplied by Faculdade de Ciências Agronômicas, UNESP/Botucatu - SP, Brazil) was prepared by dissolving $20 \mathrm{~g}$ of the fungus, ground in $200 \mathrm{~mL}$ of distilled water, at room temperature $\left( \pm 25^{\circ} \mathrm{C}\right)$, under agitation for one hour. The solution was pre-filtered and followed by filtration in $0.22 \mu \mathrm{m}$ membrane.

\section{Cell line and viruses}

HEp- 2 cells were grown in DMEM medium, supplemented with $10 \%$ of bovine fetal serum (BFS), $100 \mu \mathrm{g} / \mathrm{mL}$ of streptomycin, $100 \mathrm{UI} / \mathrm{mL}$ of penicillin, and $2.5 \mu \mathrm{g} / \mathrm{mL}$ of fungizone. The HSV-1 strain was supplied by LVEO- IMPPG- UFRJ, Rio de Janeiro, Brazil. The BoHV-1 strain was supplied by Dr. A. Alfieri, LVA, DMVP, UEL, Londrina, Brazil. Virus stocks were prepared in HEp- 2 cells and stored at $-80^{\circ} \mathrm{C}$.

\section{Citotoxicity assay}

HEp- 2 cells grown in 96-well plates for 48 hours, at $37^{\circ} \mathrm{C}$ and $5 \% \mathrm{CO}_{2}$ were treated with varying concentrations of $A$. blazei extract $(200,100,50,40,30,20,10$ and $0 \mu \mathrm{g} / \mathrm{mL})$.Cultures were observed for 7 days for alterations in normal cell morphology. The $50 \%$ cytotoxic concentration $\left(\mathrm{CC}_{50}\right)$ was determined by MTT assay kit (Sigma) according to the manufacturer's recommendation. HEp-2 cells were grown in 96-well microplates at $37^{\circ} \mathrm{C}$ and in $5 \% \mathrm{CO}_{2}$. After the formation of a monolayer, the medium was replaced with fresh medium containing different concentrations of the extract ( $62.5-10000 \mu \mathrm{g} / \mathrm{mL})$. Cells grown without extract was used as controls. The plates were incubated for three days at $37^{\circ} \mathrm{C}$ and cell viability was then determined. The $\mathrm{CC}_{50}$ was calculated as the concentration of the extract capable of reducing the optical density of the MTT product by $50 \%$ in relation to the controls by regression analysis.

\section{Antiviral activity}

The antiviral activity was done using 2 treatment protocols:

- Virucide activity: For this activity, $3.5 \times 10^{6}$ plaque forming units (PFU) of HSV- 1 and $4.6 \times 10^{6} \mathrm{PFU}$ of BoHV-1 were incubated for one hour, at $37^{\circ} \mathrm{C}$, along with the extract of A. blazei at the concentrations of 50 and $100 \mu \mathrm{g} / \mathrm{mL}$ and then inoculated in HEp-2 cell culture, at final multiplicity of infection equal to 1 (MOI). The antiviral activity was monitored by plaque reduction and indirect immunofluorescence.

- Therapeutic activity: HEp-2 cell cultures were adsorbed with HSV-1 (MOI=1) and BoHV-1 (MOI=1) for $1 \mathrm{~h}$ and after the removal of the inoculum cultures were washed with phosphate- buffered saline (PBS) treated with medium containing 50 and $100 \mu \mathrm{g} / \mathrm{mL}$ of the extract and $1.5 \%$ of agarose. The plaque assay was performed. The antiviral activity was assessed as before.

\section{Plaque reduction assay}

Plaque reduction assay was performed as previously described (17) with some modifications. HEp-2 cells, grown in 24-well plates and processed according to previous protocols were overlaid with nutrient agarose (DMEM containing 1.5\% agarose). Cultures were incubated at $37^{\circ} \mathrm{C}$ for 48 and 72 hours for BoHV-1 and HSV-1 respectively. Cultures were fixed with $10 \%$ formalin and stained with $0.5 \%$ violet crystal. The antiviral activity was defined as the percentage of plaque inhibition as follows. \% Plaque inhibition $=[1-($ Number of plaque in test $/$ Number of plaque in control) $x$ 100].

\section{Indirect immunofluorescence assay (IFA)}

HEp-2 cell cultures, grown in Leighton tubes, on cover glasses, were infected and treated according to the protocols previously cited. After 14 hours, the cultures were collected, washed with PBS and fixed with cold acetone $\left(-20^{\circ} \mathrm{C}\right)$ for 20 minutes. Briefly, the cultures on coverglass were overlaid either with rabbit anti herpesvirus antibodies supplied by Virology Department - UFRJ, Rio de Janeiro, Brazil or bovine anti herpesvirus antibodies (LVA, DMVP - UEL, Londrina, Brazil), and incubated at $37^{\circ} \mathrm{C}$ for 40 minutes. Three washings with PBS were done. After washings goat anti rabbit IgG or goat anti bovine IgG conjugated with FITC (Sigma Chem. Co. USA) was added, and maintained at $37^{\circ} \mathrm{C}$ for 40 minutes (in dark). Cover glasses were mounted in slides with $50 \%$ buffered glycerol and cells were observed in a UV light microscope. Tests were done in duplicates and 100 cells were counted by cover glass.

\section{RESULTS}

Citotoxicity tests monitored by morphological changes of HEp- 2 cells demonstrated that $A$. blazei Murill aqueous extract was innocuous at the concentrations varying from 10 to 200 $\mu \mathrm{g} / \mathrm{mL}$. The $\mathrm{CC}_{50}$, determined by MTT, was $5000 \mu \mathrm{g} / \mathrm{mL}$.

Fig. 1b shows that inhibition of $73.9 \pm 0.38 \%$ in the number of plaques was found formed when HSV-1 was treated with 100 $\mu \mathrm{g} / \mathrm{mL}$ of the extract, and $78.4 \pm 0.16 \%$ when treated with $50 \mathrm{ug} /$ $\mathrm{mL}$ under virucide protocols. Such inhibition was confirmed by test of indirect immunofluorescence (Table 1), in which a reduction of $47 \%$ in the number of fluorescent cells was observed in both concentrations. In the therapeutic protocol, inhibitions of $47.3 \pm 0.09 \%$ and $55.3 \pm 0.02 \%$ were observed for concentrations of $100 \mu \mathrm{g} / \mathrm{mL}$ and $50 \mu \mathrm{g} / \mathrm{mL}$, respectively. This inhibition was also verified by indirect immunofluorescence with a reduction of 44\%, approximately, of fluorescent cells for both concentrations (Table 1). 
For BoHV-1, under virucide protocol, reductions of $51 \pm$ $0.33 \%$ and $46.8 \pm 0.16 \%$ were observed for the concentrations of $100 \mu \mathrm{g} / \mathrm{mL}$ and $50 \mu \mathrm{g} / \mathrm{mL}$, respectively (Fig. 1a). The number of fluorescent cells was reduced in $25.4 \%$ at the concentration of $100 \mu \mathrm{g} / \mathrm{mL}$ and $16 \%$ at the concentration of $50 \mu \mathrm{g} / \mathrm{mL}$ (Table 1). Under therapeutic protocol the values were $20.9 \pm 0.31 \%$ and $23.8 \pm 0.19 \%$ inhibition for concentrations of 100 and $50 \mu \mathrm{g} / \mathrm{mL}$, respectively (Fig. 1a). By indirect immunofluorescence a reduction fluorescent cells of $19.6 \%$ and $3.5 \%$ was observed for $100 \mu \mathrm{g} / \mathrm{mL}$ and $50 \mu \mathrm{g} / \mathrm{mL}$ of the extract, respectively (Table 1).
The pre-incubation of HEp-2 cells with extract did not protect the cells from BoHV-1 or HSV-1 infection (data not shown).

\section{DISCUSSION}

A. blazei Murill has been studied for its antimutagenic effects $(5,8,10)$ mainly related to the presence of polysaccharides and protein-polisaccharide complexes, but little is known on its antiviral activity.

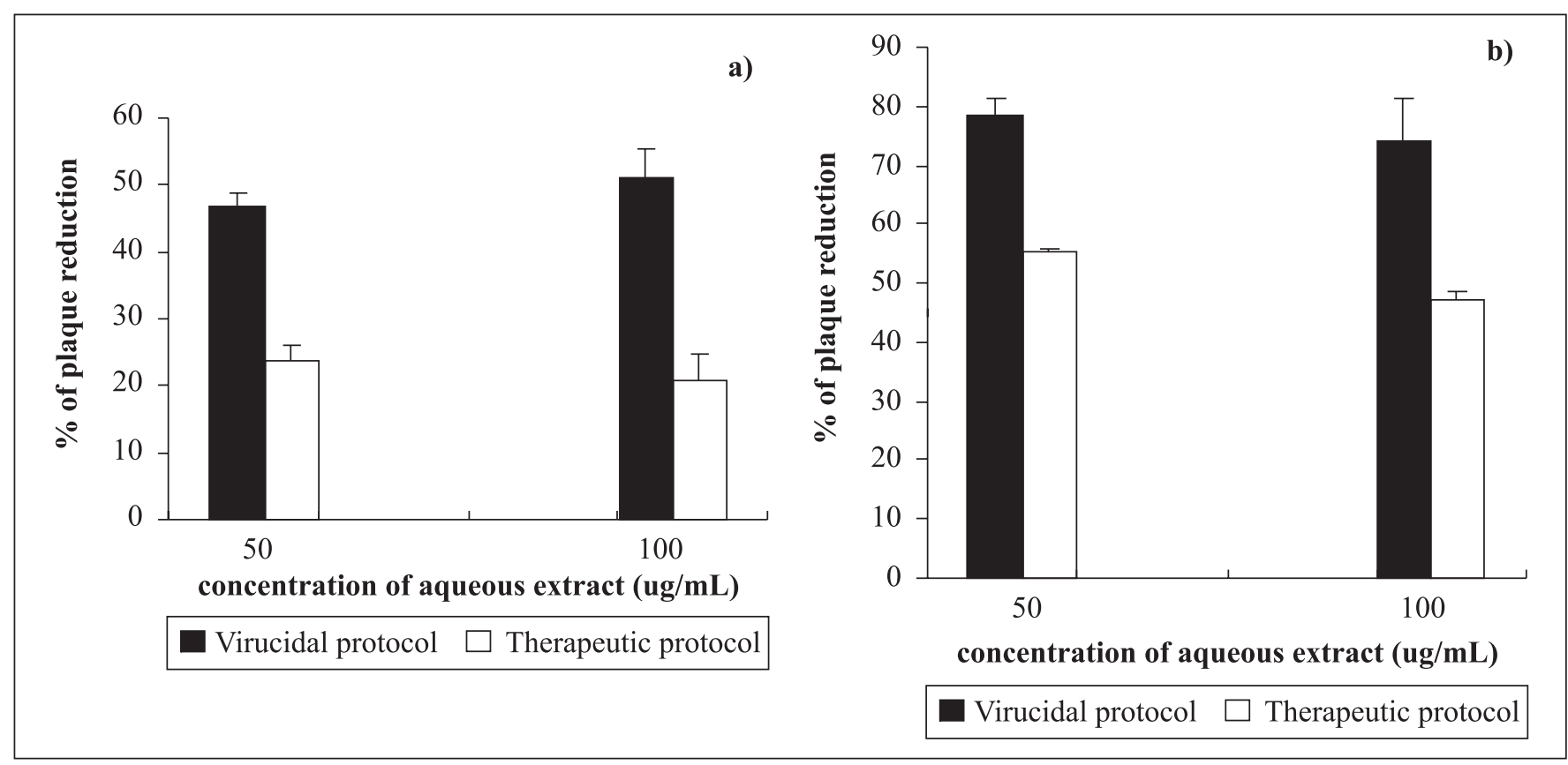

Figure 1. Percentage of reduction in plaque formation of (a) bovine herpesvirus type 1 (BoHV-1) and (b) herpes simplex virus (HSV-1) in HEp-2 cell cultures by the aqueous extract of Agaricus blazei, at concentrations of 50 and $100 \mu \mathrm{g} / \mathrm{ml}$. Under virucide protocol, the viral suspension was pre-incubated with different concentrations of the extract before inoculation and, by the therapeutic protocol, different concentrations of the extract were maintained throughout viral replication. Data are expressed as mean \pm SD. $(\mathrm{n}=3) .(* \mathrm{p}<0.05, * * \mathrm{p}<0.01$ by ANOVA $)$.

Table 1. Effect of aqueous extract of Agaricus blazei in antigen expression of BoHV-1 and HSV-1. HEp-2 cells infected with the virus pre-treated with the extract (virucide protocol) or the extract maintained throughtout viral replication (therapeutic protocol) were submitted to indirect immunofluorescence assay. Test was performed in duplicates and 100 cells with specific fluorescence were counted, by cover glass. Data are expressed as mean \pm SD. $(n=4)$.

\begin{tabular}{ccccccccc}
\hline \multirow{2}{*}{$\begin{array}{c}\text { Aqueous } \\
\text { extract } \\
(\mathrm{mg} / \mathrm{mL})\end{array}$} & \multicolumn{3}{c}{ Virucide Activity } & \multicolumn{4}{c}{ Therapeutic Activity } \\
\cline { 2 - 9 } & number of fluorescentcells & \%of inhibition & number of fluorescent cells & \%of inhibition \\
\cline { 2 - 9 } & BoHV-1 & HSV-1 & BoHV-1 & HSV-1 & BoHV-1 & HSV-1 & BoHV-1 & HSV-1 \\
\hline 0 & $37.5 \pm 0.7$ & $50 \pm 1.4$ & & & & $43.5 \pm 2.1$ & $50.5 \pm 0.7$ & \\
50 & $31.5 \pm 2.8$ & $26.5 \pm 2.1$ & 16 & 47 & $42 \pm 1.4$ & $28 \pm 3.0$ & 3.5 & 44.6 \\
100 & $28.0 \pm 2.1$ & $26.0 \pm 3.1$ & 25.4 & 47 & $35 \pm 1.4$ & $28.5 \pm 3.2$ & 19.6 & 43.6 \\
\hline
\end{tabular}


In our work, we demonstrated that aqueous extract of $A$. blazei showed antiviral effect against HSV-1 and BoHV-1 in HEp2 cell cultures. The aqueous extract was more effective regarding to virucide activity for both viruses, when compared to therapeutic action, shown by plaque reduction and the detection of viral proteins by IFA. A lower percentage of viral inhibition, in both treatment protocols (virucide and therapeutic), observed by IFA, is likely to be due to the fact that cells with fluorescent focus were counted as positive, independently on the intensity of the fluorescence emission, which might be understood as an inferior quantity of viral protein. This result was observed in cultures of infected and treated cells with two concentrations of the extract, because, besides, presenting a smaller number of fluorescent cells, they presented reduced fluorescence when compared to control cells (data not shown).

The highest viral inhibition, demonstrated in the virucide test, suggests a direct action of the extract over the viral particle, inhibiting the adsorption stage. The result found in the therapeutic test may indicate a lower efficacy in the inhibition of a posterior stage of virus replication in relation to adsorption one or even a direct action of the extract on the newly formed progeny, inhibiting the dissemination of the infection.

The virucide activity of substances derived from fungi and plants has been demonstrated for herpesvirus. Zhu et al. (20) demonstrated that a sulphated polysaccharide isolated from alga Sargassum patens inhibited up to $96 \%$ the formation of plaques in Vero cells (African green monkey kidney cells) infected by HSV- 2 (20). Sorimachi et al. (19) showed that aqueous extract and fractions obtained by alcoholic extraction of A. blazei Murill were able to inhibit the cytopathic effect of Western Equine Encephalitis (WEE) virus, poliovirus and HSV in cultures of Vero cells (19). The authors demonstrated a greater activity of the alcoholic fractions in comparison to the aqueous extract, however these effect were demonstrated in therapeutic protocol. The difference in susceptibility to antiviral agents between HSV-1 and BoHV-1 was observed to acyclovir, due to mutations in the genes of the thymidine kinase (1). In this study we observed that extract was more effective in inhibiting HSV1 infection.

The use of fungus extract as possible drugs for the treatment of herpetic infections may be an alternative for the cases of strain resistant to the existing drugs.

This raw extract seems to act on the viral particle both before its adsorption to cell and during the replicative cycle of herpesvirus. However, studies with isolate fractions of this basidiomycete might clarify its mechanism of action.

\section{ACKNOWLEDGEMENTS}

This work was partially supported by CNPq, CAPES and Fundação Araucária and it is part of R. Bruggemann M.Sc. manuscript.

\section{RESUMO}

\section{Inibição da replicação de herpes vírus humano e bovino pelo extrato de Agaricus blazei Murrill ss. Heinem em cultura de células}

O extrato aquoso de Agaricus blazei Murill ss. Heinem, um basidiomiceto nativo do Brasil, usado na medicina popular, na forma de chá, foi avaliado quanto suas propriedades antivirais contra herpes simplex tipo $1(\mathrm{HSV}-1)$ e herpes bovino tipo 1 (BoHV-1) em cultura de células HEp-2. A inibição da replicação viral foi monitorada pelos ensaio de placa e reação de imunofluorescência. $\mathrm{O}$ extrato apresentou atividade virucida mais efetiva do que terapêutica para ambos os vírus, sendo mais efetivo portanto para HSV-1, inibindo em mais de $70 \%$ o número de plaques e em cerca de $47 \%$ o número de células apresentando fluorescência específica, nas concentrações de 50 e $100 \mu \mathrm{g} / \mathrm{mL}$, nas duas técnicas utilizadas. Os resultados obtidos sugerem que o extrato aquoso de A. blazei deve agir principalmente sobre a partícula viral, embora a inibição durante o ciclo replicativo do vírus não deva ser excluída.

Palavras-chave: Agaricus blazei, BoHV-1, HSV-1, atividade antiviral

\section{REFERENCES}

1. Babiuk, L.A.; Acres, S.D.; Misra, V.; Stockdale, P.H.G.; De Clercq, E. Susceptibility of Bovid Herpesvirus 1 to Antiviral Drugs: In Vitro Versus In Vivo Efficacy of (E)-5-(2-Bromovinyl)-2'-Deoxyuridine. Antimicrob. Agents Chemother., 23, 715-720, 1983.

2. Brideau, R.J.; Knechtel, M.L.; Huang, A.; Vaillancourt, V.A.; Vera, E.E.; Oien, N.L.; Hopkins, T.A.; Wieber, J.L.; Wilkinson, K.F.; Rush, B.D.; Schwende, F.J.; Wathen, M.W. Broad-spectrum antiviral activity of PNU-183792, a 4-oxo-dihydroquinoline, against human and animal herpesviruses. Antiviral Res., 54, 19-28, 2002.

3. Daba, A.S.; Ezeronye, O.U. Anti-cancer effect of polysaccharides isolated from higher basidiomycetes mushrooms. Afr. J. Biotechnol., 2, 672-678, 2003.

4. De Clercq, E. Antiviral drugs in current clinical use. J. Clin. Virol., 30, 115-133, 2004.

5. Delmanto, R.D.; Lima, P.L.A.; Sugui, M.M.; Eira, A.F.; Salvadori, M.F.; Speit, G.; Ribeiro, L.R. Antimutagenic effect of Agaricus blazei Murrill mushroom on the genotoxicity induced by cyclophosphamide. Mutat. Res., 496, 15-21, 2001.

6. Field, H.J. Herpes simplex virus antiviral drug resistance - current trends and future prospect. J. Clin. Virol., 21, 261-269, 2001.

7. Gilbert, C.; Bestman-Smitu, J.; Boivin, G. Resistance of herpesviruses to antiviral drugs: clinical impacts and molecular mechanisms. Drug Res. Update, 5, 88-114, 2002.

8. Guterrez, Z.R.; Mantovani, A.F.; Eira, A.F.; Ribeiro, L.R.; Jordão, B.Q. Variation of antimutagenicity effects of water extracts of Agaricus blazei Murrill In vitro. Toxicol. In Vitro, 18, 301-309, 2004.

9. Hinkley, S.; Hill, A.B.; Srikumaran, S. Bovine herpesvirus-1 infection affects the peptide transport activity in bovine cells. Virus Res., 53, 91-6, 1998. 
10. Menoli, R.C.R.N.; Montovani, M.S.; Ribeiro, L.R.; Speit, G.; Jordão, B.Q. Antimutagenic effects of the mushroom Agaricus blazei Murrill extracts on V79 cells. Mutat. Res., 496, 5-13, 2001.

11. Mothana, R.A.A.; Awadh Ali, N.A.; Jansen, R.; Wegner, U.; Mentel, R.; Lindequist, U. Antiviral lanostanoid triterpenes from the fungus Ganoderma pfeifferi. Fitotetapia, 74, 177-180, 2003.

12. Nakajima, A.; Ishida, T.; Koga, M.; Takeuchi, T.; Mazda, O.; Takeuchi, M. Effect of hot extract from Agaricus blazei Murill on antibody-producing cells in mice. Int. Immunopharmacol., 2, 1205 1211,2002

13. Nakamichi, K.; Matsumoto, Y.; Otsuka, H. Bovine Herpesvirus $1 \mathrm{U}_{\mathrm{s}}$ ORF8 Protein Induces Apoptosis in Infected Cells and Facilitates Virus Egress. Virology, 304, 24-32, 2002.

14. Oliveira, J.M.; Jordão, B.Q.; Ribeiro, L.R.; Eira, A.F.; Montovani, M.S. Anti-genotoxic effect of aqueous extracts of sun mushroom (Agaricus blazei Murril lineage 99/26) in mammalian cells in vitro. Food Chem. Toxicol., 40, 1775-1780, 2002.
15. Piraino, F.; Brandt, C.R. Isolation and partial characterization of an antiviral, RC-183, from the edible mushroom Rozites caperata. Antivir. Res., 43, 67-78, 1999.

16. Roizman, B.; Knipe, D.M. In: Field's Virology, $4^{\text {th }}$ ed. Philadelphia: Lippincott Williams and Wilkins Co., 2001, pp. 2399-2460.

17. Rovozzo, G.C.; Burke, C.N. A Manual of Basic Virological Techniques. Prentice-Hall, Inc., 1973, pp.126-136.

18. Saboulard, D.; Gaspar, A.; Roussel, B.; Villard, J. New antiherpetic nucleoside from a Basidiomycete. Life Sci., 321, 585-591, 1998.

19. Sorimachi, K.; Ikehara, Y.; Maezato G.; Okubo, A.; Yamazaki, S.; Akimoto, K.; Niwa, A. Inhibition by Agaricus blazei Murill Fractions of Cytopathic Effect Induced by Western Equine Encephalitis (WEE) Virus on VERO Cells In Vitro. Biosci. Biotechnol. Biochem., 65, 1645-1647, 2001.

20. Zhu, W.; Chiu, L.C.M.; Ooi, V.E.C.; Chan, P.K.S.; Ang Jr, P.O Antiviral property and mode of action of a sulphated polysaccharide from Sargassum patens against herpes simplex vírus type 2. Int. J. Antimicrob. Agents, 24, 81-85, 2004. 